\title{
Intercultural theatrical encounter and the dramaturgy of surtitles
}

\author{
Geraldine Brodie
}

Centre for Translation Studies, University College London, London, United Kingdom

Gower Street, London WC1E 6BT

g.brodie@ucl.ac.uk

ORCiD ID: 0000-0002-4800-1403

Twitter: @GeraldineBrodie

LinkedIn: Geraldine Brodie

Facebook: Geraldine Brodie

Geraldine Brodie is Associate Professor in Translation Theory and Theatre Translation in the Centre for Translation Studies at University College London. Her research centres on theatre translation practices in contemporary London, on which topic she speaks and publishes widely, including contributions to translation studies handbooks and encyclopedias. Recent publications include her monograph The Translator on Stage (Bloomsbury, 2018), the volume Adapting Translation for the Stage, co-edited with Emma Cole (Routledge, 2017) and the special issue, 'Martin Crimp: playwright, translator, translated', of the Journal of Adaptation in Film \& Performance (2016:1), co-edited with Marie Nadia Karsky. Geraldine Brodie is a Senior Fellow of the Higher Education Academy, a panel Associate of ARTIS (Advancing Research in Translation and Interpreting Studies) and an editorial advisor for UCL Press. In addition to her role at UCL, Geraldine Brodie is a chartered accountant, a school governor and Chair of Actors Touring Company. 


\title{
Intercultural theatrical encounter and the dramaturgy of surtitles
}

\begin{abstract}
Theatre surtitles have tended to be seen as a necessary inconvenience. However, recent technological developments have streamlined the provision of translated captions and these advances are influencing awareness of and attitudes to the use of surtitles in theatre spaces. Taking the ITA's Roman Tragedies as an illustration, this article examines the application of surtitling technology in theatre translation. The intermedial performance of surtitles positions surtitles within new media dramaturgy, creating a form of interlinear translation. The dramaturgical effect of the integration of surtitles into production demonstrates how technological intervention can operate to co-produce the humanity of intercultural theatrical encounter.
\end{abstract}

Keywords: dramaturgy, interlinear translation, intermedial performance, surtitles, theatre translation

\section{Introduction}

In his 1923 essay on the task of the translator, Walter Benjamin envisaged the construction of translation as an integral element within the creation of a text. 'All great writings contain their virtual translation between the lines', he insisted, concluding that the interlinear version is the fundamental image or ideal of all translation $\left(1968\right.$, p. 96) ${ }^{1}$. If, as Benjamin suggests, translation is pre-inscribed within a text, I contend that a staged translated text is a particularly significant site to study the revelation of inherent translation due to the performative effect of the interpretive staging process. Furthermore, where translation is conveyed by means of text projected on screen in the form of surtitles, the intermediality and interlinearity of translation is overtly displayed to the audience. This article investigates emerging methodologies for composing and incorporating translated surtitles in the staging of international theatre

\footnotetext{
${ }^{1}$ My translation.
} 
productions. I analyse the integration of translation into live performance from a dramaturgical perspective and examine the extent to which the intermedial positioning and display of surtitles can be interpreted as an interlinear marker of the significance of the underlying translational act in theatrical communication.

Theatre surtitles have tended to be seen as a necessary inconvenience, permitting a limited access to performance in another language. However, recent technological developments have streamlined the provision of translated surtitles and these advances are influencing awareness of and attitudes to their use in theatre spaces; this is evidenced, for example, by the increasing demand for surtitles in opera and for the deaf and hard of hearing. This article discusses the significance of these developments and then goes on to examine the application of audiovisual technology in the context of international theatre. I advocate the fruitfulness of exploring the relationship between surtitles and intermedial theatre techniques, defined by Patrice Pavis as 'exchanges and interactions between different media on stage: screen-based audiovisual technologies, most recently involving the projection of film, digital-video and other virtual and new media images onto the stage and incorporated into a production' (2013, p. 143). Such technological advances offer the opportunity to design productions with the intention of centring translated surtitles within the set rather than relegating translation to the periphery. I argue that integrating surtitles within live intermedial theatre demonstrates the inter-relation between human embodiment and nonhuman representation within theatrical creativity, drawing attention to intercultural exchange and thus exemplifying the propensity for action of humannonhuman assemblages. Drawing on Deleuze and Guattari, Suzanne McCullagh defines assemblages as 'multiplicities composed of bodies, desires and enunciations' (2019, p. 152). The intermingling of human practitioners and electronic imagery in live performance is an example 
of such multiplicity. These issues are illustrated with reference to the translation and surtitling practices of the Dutch theatre company Internationaal Theater Amsterdam (ITA), focusing on the production Romeinse Tragedies (Roman Tragedies), a six-hour Dutch-language amalgamation of Shakespeare's Coriolanus, Julius Caesar and Antony and Cleopatra, first devised in 2007 and shown at the Barbican Theatre, London with English surtitles in 2009 and 2017. This production explored the potential of theatrical intermediality by incorporating surtitles into its presentation in a variety of modalities. I argue that the dramaturgical effect of the integration of surtitles into this production showcases how technological intervention can operate to co-produce the humanity of intercultural theatrical encounter.

\section{Theatre, translation and surtitles}

Although my introduction employs the term 'surtitles' to describe projected translated text in the theatre, the terminology for this relatively recent innovation in translation has developed over time and has some variation in usage in both practical and theoretical contexts. For research purposes, theatre surtitling is currently examined as a constituent of audiovisual translation research. This has not always been the case; a survey of the taxonomy of screen-projected text sheds some light not only on the usage of the term 'surtitle' but also its relationship to technology and the 'liveness' of human performance. Aline Remael considers that 'the earliest form of [audiovisual translation] may have been translation of intertitles in silent films' (2010, p. 12). Certainly, the relationship between screen and text has been a key feature in this field, to the extent that some researchers have insisted that screen translation relates only to 'the translation of recorded audiovisual material' and not 'the on-stage translation of theatre plays and operas - mainly performed 
with the use of surtitles or supertitles' (Karamitroglou, 2000, p. 2). The encounter on stage between live performed text and pre-recorded translation can be a challenging factor in conveying audiovisual translation, but the shared elements among audiovisual texts, 'the integration of the verbal component in a complex sign system meant to be watched, heard and sometimes read' (Remael, 2010, p. 13), bring theatre surtitles into the sphere of audiovisual translation activity. Nevertheless, the terminology varies between procedural types and geographical activity. Jorge Díaz-Cintas and Gunilla Anderman provide a simple distinction with regard to the placing of this text: 'While subtitles are translated texts usually displayed below the image, as on a cinema or television screen, surtitles are most often displayed above the stage, in live opera and theatre performances' (2009, p. 10). Their terminology in making this distinction, however, adopts British English usage. Luis Pérez González points out that subtitles are known in American English as 'captions' (2020, p. 31) and Remael gives 'supertitling' as the American term for surtitling (2010, p. 13). Audiovisual terminology is further complicated by the expansion of research to include screen text that has not been translated; subtitling for the deaf and hard of hearing (often referred to as SDH) harnesses technology to create subtitles in the language spoken on screen or stage. Subtitling practitioners themselves may use these terms differently; for example, 'captions' to denote same-language text (as in SDH) and 'subtitles' where translation is involved. I adopt the prevailing British English approach, describing theatre titles as surtitles. Avoiding the overarching (and predominantly operatic) connotations of supertitles suggests a flexibility of positioning that renders this term apposite for theatre, as I illustrate in this article. I also refer to screen text as 'captions'. In both cases, I use these terms whether or not intralingual translation has taken place because even in same- 
language captions there will always be an element of linguistic intervention and transposition between the source and target text.

This article, however, discusses surtitling in theatre. In English-speaking theatre it is relatively unusual to find subtitling used as a vehicle for translation of a play written in another language; standard practice is for a foreign-language text to be performed in English translation. In the UK, as in most English-speaking countries, plays originally composed in foreign languages tend to be translated into English for presentation in new productions. A 2013 analysis of the British theatre repertoire found that 'the total number of original and revived translations $[\ldots]$ makes up barely one-tenth the number of original adult [straight] plays' (British Theatre Conference, 2015, p. 13). Although the authors of the report were disappointed by this statistic, it nevertheless places the proportion of translated theatre at a higher level than the number of translations in British and American book production of 'roughly between 2 and 4 percent' identified by Lawrence Venuti (2008, p. 11). Furthermore, theatre displays a marked difference from other modes of translation dissemination, such as publishing or screen media, in that it will often publicise the names of both the source text and the performance text authors, thus highlighting the transpositional act. Interlingual translation is less clearly marked, however; established theatre practitioners, usually English-language playwrights, are often named as adaptors, while the expert linguists who prepare the translations used by these writers to create a performance text are mentioned in very small print, if at all ${ }^{2}$. Theatre translation therefore is a multi-agency process, especially when the contributions to the performed text of the creative theatre practitioners and actors are taken into account. However, this collaborative

\footnotetext{
${ }^{2}$ For a discussion of literal translation in theatre, see Brodie (2018).
} 
translation has varying degrees of visibility with theatre specialism tending to be prioritised above linguistic expertise. One area where translation is highly visible, if not the agency of the translator (who again is frequently uncredited or relegated to the later pages of the theatre programme), is in the relatively infrequent surtitled productions. Two key factors combine to point out to the audience that the source text comes from a different language and culture: firstly, the language spoken on stage is not English and, secondly, the English translation is provided in surtitles. This is in contrast to a translated play performed in English in which the underlying language and culture may struggle to maintain a presence in the English-language production.

Surtitled theatre productions for plays performed in another language are more likely to be performed in venues specialising in international festival material, such as the Barbican Theatre in London. However, surtitled opera has become the norm in Britain. Lucile Desblache considers 'the introduction of surtitles in every opera house [in Britain] within the last two decades of the twentieth century [to be] the most spectacular development in accessibility', to the extent that most opera houses in Britain now project surtitles even when operas are sung in English (2013, p. 34). Accessibility, in the context of opera, refers to opening this traditionally elite cultural art form to 'a higher proportion of first-time goers, younger participants belonging to a wider social range, and of new productions and contemporary creations' (Desblache, 2013, p. 28). Providing English surtitles for libretti that have been composed in, or already translated into, English makes it easier for unfamiliar audiences to follow the words being sung, especially in larger opera houses 'where clear diction is often challenging due to the acoustics' (Desblache, 2013, p. 34). However, captioning technology also renders language transfer more accessible. 
Where opera is sung in the language of original composition, electronic advances now enable audiences to select captions in the language of the opera house in which they are seated or in a select range of other languages. This machinery is also a means of expanding language accessibility internationally. For example, in December 2018 I attended a performance of Johann Strauss's operetta Wiener Blut sung in Estonian (as Viini Veri) at the Vanemuine Theatre, Tartu. English and Finnish surtitles were on display above the stage and I could in addition control my own captioning by connecting to the Sophokles application from my mobile device, from where a Russian caption option was also available. That the emphasis of such tools is on accessibility rather than highlighting translation, however, is demonstrated by the absence of German, the original language of the work. The languages offered were those most likely to be spoken or understood (as a mother-tongue or other language) by an audience in Estonia. In this example, technology operates to bring spectators together around a performance, but less so around perceptions of intercultural transfer between source and target cultures. The sources of funding for the Sophokles initiative demonstrate its principal motivations. The application was developed by Estonian software developer Tanel Teemusk in collaboration with three Estonian theatres: Vanemuine, Rakvere Teater and Teater NO99 (now closed). Funding was provided by the European Social Fund project 'Activities Supporting Integration in Estonian Society' and its sub-activity 'Increasing the Capacity for Presenting Information in Other Languages' ${ }^{3}$. Accessibility and integration are thus the key impulses for this project. Nonetheless, analogue indications of the source culture were clearly illustrated; the

\footnotetext{
${ }^{3}$ The author is grateful to Mikk Männaste, Information Technology Director of the Vanemuine for this information (Männaste, 2019).
} 
title of the piece locates the operetta in Vienna and the director, Giorgio Madia, expressed the aim of his staging to '[unfold] the scent of [the 1815 Congress of Vienna] and the historical fact' of the political event (Vanemuine Theatre, 2018).

Digital technology has enhanced the range of language captions on offer in many opera houses internationally. Screens inserted in theatre seatbacks permit spectators to choose which language they wish to follow - or to switch off. An informal survey carried out in 2017 located seatback captions in the opera houses of Barcelona, Berlin, New York, Oslo, Valencia, Milan and Vienna ${ }^{4}$. Languages available tended to be, again, the languages of the likely audience, plus English. Opera surtitles in London are less multilingual, and also less focused towards the individual audience-member. The Royal Opera House provides a seating plan on its website to indicate seats that have no surtitle view and those which can only view surtitles on a local monitor (because views of the main surtitles projected above the stage are restricted). The website states, 'Surtitle translations of what is being sung are supplied for all opera performances, including those sung in English’ (Royal Opera House Covent Garden Foundation, 2019). The implication here is that surtitles are only available in English, whether as translations or as textual support. Nevertheless, I consider that the demand for English surtitles in English-language opera signals a trend across a range of media of the increasing acceptability of surtitles for English-language audiences, which provides some insight into the use of surtitles for translation in spoken theatre.

\section{Performing captioned translation}

\footnotetext{
${ }^{4}$ The survey was carried out by the anonymous blogger @ operatraveller with additional contributions from readers of the blog (operatraveller.com, 2017).
} 
The interaction of surtitles with live performance presents a challenge for theatre practitioners on and off stage. Translated captions are prepared in advance based on the script or libretto that is to be performed. However, theatre and opera surtitles cannot be pre-programmed into the recording as in film but have to be displayed as the equivalent words or phrases are spoken or sung on stage. Furthermore, even where same-language surtitles are in operation, the captioned words will not necessarily reflect the spoken dialogue (or sung text). There are well-developed conventions around subtitling based on the constraints of screen projection. As Roger Hillman observes, 'These limits are imposed by the need to minimize intrusion on the visual image, and by reading rates, bearing in mind that these lag behind comprehension of speech via listening' (2011, p. 384). Jan-Louis Kruger sets out the practical constraints imposed on subtitlers (and, indeed, the composers of captions generally) in relation to the numbers of characters per title, the number of lines projected (usually no more than two) and how the lines are divided. Other considerations include how the captions relate to scene changes, the synchronicity of the captions with the action and how captions reflect the visual and auditory rhythm of the work (Kruger, 2008, p. 82). In a live theatrical environment, Jonathan Burton notes, based on his experience in surtitling for the Royal Opera House, that 'the pacing of the surtitles should be kept slow and simple, to avoid distracting the audience. [Changes] should come at musically logical points, $[\ldots]$ vital dramatic revelations should not be anticipated [...]. The aim is transparency: we are trying to convey what is being said, not how it is being said - the singer is doing that for us' (2009, pp. 32-33 $)^{5}$. All these factors apply to surtitles in plays, but with additional complexity; the dynamics between text and music results in a visual and auditory experience for an opera audience that is less dependent on textual content. Burton recounts that where a sung text is

\footnotetext{
${ }^{5}$ Burton's emphasis.
} 
repetitive 'the title can be left up for a long period', for example. In text-based theatre, audience expectations are likely to be for the captions to be more closely aligned to the spoken word.

A significant point of similarity between surtitling in opera and theatre is the demand placed on the timing of the projection of captions due to the live nature of the performance. Gay McAuley, investigating the relationship between performers and spectators, identifies an overriding space in which these two constitutive groups 'meet and work together to create the performance experience' (1999, p. 26). Since no two audiences will be alike, no performance can be exactly replicated, however well-rehearsed the performers. Furthermore, contemporary developments in postdramatic theatrical forms, among which Hans-Thies Lehmann includes 'documentary theatre, installation theatre, comedy, political theatre, the theatre of images, theatre bordering on performance art' in addition to conventional conceptions of tragedy (2016, p. 2), have widened the scope for devised, improvised and contingent performances for which the text is one of many unstable elements. If surtitles are to respond to the live qualities of performance, they require an element of 'liveness' themselves. A description of the Met titling process by the dramaturg, who oversees 'Met Titles' at the Metropolitan Opera in New York, demonstrates how this element is captured.

The titles themselves are performed by a team of two people at every performance: a cue caller and an operator. The cue caller follows the score closely and watches a video monitor and wears headphones to hear an audio feed and cues the operator (by saying 'go') every time a new title is to appear or go to black in between titles. The operator presses the button that makes the title or black [screen] appear on the seatback screens. The cue caller is a skilled musician who can follow the performance carefully and make allowances for variations in performances in terms of entrances, dialogue, etc.. ${ }^{6}$

That the Met Title operators are described as 'performers' and the performance credentials of the

\footnotetext{
${ }^{6}$ The author is grateful to Paul Cremo, the Dramaturg and Director of Opera Commissioning Programs,
} Metropolitan Opera, for this information (Cremo, 2014). 
cue caller are also highlighted indicates the crucial role of this activity within the performance as a whole.

Since surtitling is more established in opera than in theatre, its procedures tend to be more systematised. Theatre surtitling should be similarly responsive to live performance. Estella Oncins, however, points out that, in contrast to opera houses which maintain in-house titling departments, 'theatrical surtitling remains a sporadic practice for programmed performances in a different language and is largely outsourced to specialized companies' resulting in variations of technique and approach for each surtitled production (2015, p. 53). Oncins's observation demonstrates the specialism of surtitling, but also the tendency to treat this aspect of a production as extraneous to the core performance. Theatre companies who tour internationally on a regular basis - and who have the resources - include a specialist surtitler in their team to ensure that the director's vision for the production is transmitted across all media. The Schaubühne theatre company, based in Berlin, is one such example. In October 2019 alone, the company performed productions from its current repertoire in Zagreb, Paris, Guanajuato and Tokyo, including a German-language Hamlet directed by Thomas Ostermeier, which also visited the Barbican Theatre in London in 2011. The English surtitles were created by translator Uli Menke, who was present in London to operate the surtitles. Although Shakespeare's text had been translated into contemporary German by the playwright Marius Von Mayenburg, Menke opted not to translate Von Mayenburg's text back into English (because 'it's too well known') and worked with the English text to 'shorten each line, to simplify it by choosing the main ideas and cutting the excursions'. Menke prefers to use his own laptop, connected to the host theatre's system, and specialist software Visiotitre which displays both German and translated surtitles on his personal screen but only projects the translation. He then operates the surtitles alone, following the 
German dialogue to cue the projection of the surtitles. Menke stresses that he aims to keep his surtitles very short so that the audience can follow both the text and the action on stage with ease. Additionally, Menke considers that the positioning of the surtitle projection screen is critical to the speed of the audience's response to the captions ${ }^{7}$. Menke illustrates the professional theatrical engagement that brings surtitling within the ambit of performance. Furthermore, as he describes the decision-making process for surtitle positioning, a consultation is held between the set designer, technical director, lighting designer, surtitle operator and director of the production before the latter makes the final judgement. This shows the collaborative activity of the production team in combining surtitling with performance; it also demonstrates that the ultimate effect has to conform to the overriding vision of the director, who co-ordinates both human and nonhuman elements in creating the active force of the production.

The nonhuman element in the performance of surtitles is even more marked in the most recent technological developments. Alina Secar itemises advances in captioning technology that 'have revolutionized the way captioning is created in venues where accessibility services are available', in particular smart glasses, for which the individual wearer can control the timing and text projected onto the glasses, and the display of captions using speech recognition tools (2018, p. 138). Secar describes the Open Access Smart Capture initiative launched by the Royal National Theatre in London in 2017 in which captions are automatically cued, 'using speech technology and other triggers from the sound and lighting desk' (2018, p. 139). In replacing the human cue caller with a nonhuman performer capable of engaging with the complexities of live performance, this technology demonstrates the capacity for action of human-nonhuman assemblage. Approaching the intricacies of surtitle creation and projection as integral to

\footnotetext{
${ }^{7}$ The author is grateful to Uli Menke for this information (Menke, 2015).
} 
performance underlines the significance of conjoining human performance with technology; it also indicates the contribution made by the surtitles to the dramaturgy of the production.

\section{The dramaturgy of surtitles}

Adam Versényi describes dramaturgy as 'the architecture of the theatrical event, involved in the confluence of components in a work and how they are constructed to generate meaning for the audience' (Versényi, 2010, p. 176). Surtitles fit well within this definition: the physicality of their projection is architectural, their supplemental relationship to the spoken dialogue (both from the perspective of translation and abbreviation) creates a fusion of theatrical elements and their motivation is to enhance the communication of a production to its spectators. The interaction between the surtitles and the text spoken by the actors therefore forms part of the dramaturgical narrative of the production. The constraints of surtitling, which force the translator to foreground key elements of the source text, can also have the consequence of highlighting the focus of the creative team, especially the vision of the director for the mise en scène of the production. Defined by Thomas Postlewait as the stage setting and 'all other related aspects of the spatial and temporal order of theatrical performance $[\ldots]$ including the actions and movements of all the performers' (Postlewait, 2010, p. 396), the mise en scène is the essential template for how a production connects with its audience. Surtitles, significant from both the aspect of positioning (spatial order) and sequencing with the spoken text (temporal order), are part of the dramaturgical apparatus available to a director in forging that connection.

Situating surtitles within the dramaturgy of performance interrogates the extent to which surtitling can be employed as a tool to influence the audience's negotiation of a production. Marvin Carlson sees on-stage translation as a 'third speech' that comes into play 'when a human or mechanical "translator" is interposed between one language and other' (2006, p. 182). The 
resulting 'side text' has 'grown beyond [the function of simple translation device] to enter more directly into the aesthetic frame of the theatrical production' (Carlson, 2006, p. 181). Viewed from this perspective, surtitles - and the negotiation of language that they represent - become integral to the transmission of a translated play. Furthermore, the disembodied form of translation represented by surtitles requires human actors to perform with (or against) a nonhuman component. I have heard from actors that they find working with surtitles places them under extra pressure to reproduce their lines exactly, aware that their audience can follow the projected captions as they speak. Performance of surtitles thus affects and presents a challenge for theatre practitioners beyond the surtitle creators and operators. This challenge can be taken up by theatre-makers, however, to bring surtitles explicitly into the mise en scène. Louise Ladouceur, pursues the concept of playful surtitles that '[exceed] their primary function of reproducing the message delivered on stage' (2013, p. 120). In the case of the bilingual Canadian production she describes, the surtitles displayed meaningless symbols at one particular point, requiring the audience 'to interpret this translation on their own' (Ladouceur, 2013, p. 121). The director Romeo Castellucci goes further by using surtitling techniques to subvert the narrative of his productions. Alan Read, as a member of the audience for Castellucci's Purgatorio, a retelling of Dante's Divine Comedy performed at the Avignon Festival in 2008, records

a longish period where the 'stage directions' in the surtitles diverge from what we see on stage. Castellucci would appear in this commentary to be less concerned with glossing an action that has the inevitability of tragic fate about it than interrupting each stage of a reading (our witness) that might presume to collapse sounds, spoken words and writing to a consistency that conceals multiple abuses elsewhere (Read, 2010, p. 262).

These two examples demonstrate how the content of surtitles can amplify the audience's interaction with both the production and the concept of translation.

Theatre-maker Catherine Alexander, describing the reception of Complicite's intermedial production The Elephant Vanishes, performed in Japanese with English surtitles, notes, 'Most 
satisfyingly, there was no mention of this being a surtitles performance. Perhaps in this instance the visual mode helped to integrate this all-too-often irritating device and make it just another way of sharing a story' (Alexander, 2010, p. 79). Including surtitles in an overarching 'visual mode' of production promotes a further feature of the dramaturgy of surtitles in addition to the textual content: where and how the captions are projected. In these circumstances, technology becomes increasingly significant in the interaction between human theatre practitioners and their audiences. Christopher Balme argues that 'if we define theatre as a hypermedium, then one of those features is the potential to realize and represent all other media. [Theatre] must define its relationship to the other media in terms of openness and productive exchange' (Balme, 2008, p. 91). Incorporating surtitles among theatrical media promotes such openness and invites a reassessment of human and technological agency in linguistic exchange.

The significance of technology for theatre is recognised in the concept of NMD (New Media Dramaturgy), 'the technologies and techniques of new media in relation to the dramaturgical function of translating ideas into practice and compositional awareness' (Eckersall, Grehan, \& Scheer, 2015, p. 376). NMD accepts the challenge of bringing non-human technology into play with the essentially human nature of 'live' theatre; as a practice, 'NMD changes everything for the spectator. The landscapes of production and reception are unrecognizable $[\ldots]$ tools operate within or often control the performance landscape. As a result the act of responding changes and it must' (Eckersall, et al., 2015, p. 376). Thus the audience is drawn into the interplay between human and machine agencies. Ilinca Todorut points out the potential for dramaturgies engaging with digital culture to foster Jacques Rancière's 'emancipated spectator' (Rancière, 2008), the active interpreter and appropriator of stories: 'intermediality $[\ldots]$ valorizes the positive values of the in-between, the hybrid, the fluid, and the 
open-ended' (Todoruţ, 2015, p. 499). This enabling hybridity of intermedial theatre is also a specific feature of surtitles, as Yvonne Griesel identifies. In Griesel's view, this hybridity and its attendant visibility offer creative opportunities for 'courageous' translators (Griesel, 2009, p. 125). Locating surtitling within new media dramaturgy thus opens possibilities for theatre practitioners, translators and audiences to work with technology to interrogate and foreground translation and, in consequence, their connections with each other. Lucile Desblache, reflecting on hybridity in the context of posthuman theory, considers that 'successful post-human societies will adopt non-linear and permeable visions of frontiers that are instruments of relationships' (2012, p. 249). I argue that the interplay between human and nonhuman elements in intermedial surtitling illustrates her prediction: the hybridity of surtitles and their interlinear qualities demonstrate the blurred boundaries that enable the interrogation of relationships within and across languages and cultures. Analysing the use of surtitles in the multilingual context of Singapore theatre, Alvin Eng Hui Lim argues that surtitles force audiences to 'shift their gaze from the speaking body to the mediated text and back. Instead of performing language as a given identity or a sense of linguistic purity, translation contributes to the critical dramaturgy required to question language at the most personal and emotional level of self' (Lim, 2020, p. 97). The dramaturgy of surtitles employs technology to engage with humanity in one of its most essential qualities: the ownership and use of language. The case of Roman Tragedies provides an example of the potential impact of surtitles integrated into production's mise en scène.

\section{Positioning surtitles in performance}

Ivo van Hove is the Belgian artistic director of Dutch company Internationaal Theater Amsterdam (ITA), which was formed by a merger between Toneelgroep Amsterdam and Amsterdam Stadsschouwburg in 2018. Van Hove is known for the extremity of his adaptational 
approach to classic theatrical and cinematic performance texts, presenting internationally recognised work, such as Shakespeare's Henry V, Henry VI and Richard III (amalgamated into a four-and-a half-hour production as Kings of War) and Ingmar Bergman's Scenes from a Marriage (a reworking of the television series and film), performed in Dutch translation in Amsterdam and around the world. Van Hove lives and works across national boundaries, both as a Dutch-speaking Belgian directing a theatre company based in the Netherlands and as an international theatre practitioner introducing Dutch-language theatre to audiences unaccustomed to hearing the Dutch language. ITA's touring productions are performed in Dutch with surtitles in the language of the host country but even at the company's base in Amsterdam English surtitles are available every Thursday and all through August so that, according to Toneelgroep Amsterdam's previous website, 'English speakers can truly experience the multi-layered approach to Dutch theatre in all its facets' (Toneelgroep Amsterdam, 2017). Furthermore, Van Hove insists on the accessibility and visibility of surtitles for audiences, the website noting the technical specifications that 'surtitles are projected as close to the actors as possible and are always controlled manually’ (Toneelgroep Amsterdam, 2017). This policy chimes with the 'relational dramaturgic action' identified by Peter Boenisch in Van Hove's productions, permitting connections at an individual level with the spectators (Boenisch, 2014a, p. 228). Just as the spectators of Van Hove's productions can find themselves face-to-face with the actors (by being invited onto the stage, for example), surtitles are drawn into the production and projected within the performance arena, not superimposed or distanced from the action. Actors (and audiences) thus engage with surtitles on a personal level. ITA's surtitles perform a function beyond that of transposing the Dutch lines into English. They provide a metatextual, interlingual commentary on the action of the play, reflecting the cultural transformation taking place on 
stage. This function was all the more extreme when English surtitles were presented to an audience familiar with the original Shakespearean text, as was the case for the performances of Roman Tragedies at the Barbican Theatre in London in 2009, and a further visit in 2017.

The amalgamated trilogy Roman Tragedies was first created in 2007 and continues to tour extensively around Europe, North America and Australia. The production is described by Katherine Rowe, in Shakespeare Quarterly, as a 'sustained meditation on modern political theater' (Rowe, 2010, p. iv). A consecutive staging of Shakespeare's three plays, Coriolanus, Julius Caesar and Antony and Cleopatra, the production approaches six hours in length. In London, it was performed in Dutch with English surtitles. In an interview published in the Barbican Theatre programme, the director, Ivo van Hove, insisted, 'we have simply made a new translation' (Perrier, 2009, p. 8). However, the amalgamation of three plays, the contemporary setting, the male roles played by women and the stage-audience interactivity combined to create a strikingly overt reinterpretation and condensation of Shakespeare's work. In London, the potential controversy of this approach was further reinforced by the English surtitles, negotiating between the Shakespearean text and a back-translation of the performed Dutch script.

Even given the extended duration of the performance, Van Hove's amalgamation device necessitated significant paring of the text. Van Hove was clear that this was part of his directorial strategy: he wished to focus on the politics and personalities of the dramas, and therefore omitted the crowd scenes and battles, limiting his cast to fifteen actors and filling the stage with technology rather than people. The incorporation of surtitles into this scenario demonstrates their role as additional narrators and actors in the stage drama. In a newspaper interview while on tour in Montreal, Van Hove explains that intermediality is a crucial tool in the portrayal of the rationale of his production: 'These days, politicians bring their message through the lens of a 
camera. [...] When you go out [of the theatre], you can also watch from the lobby. Everywhere you cannot escape the performance and the politics' (Nestruck, 2010). Thus the screens and media displays were a crucial feature not only of the performance techniques but also of the interpretation of Shakespeare's content that the ensemble wished to communicate to the audience.

Roman Tragedies did not only reference contemporary issues through the use of modern dress and modern Dutch, it also pushed intermedial theatre techniques beyond the mise en scène into the auditorium. The set resembled an invitation-only airport departure lounge, with a mass of screens of varying sizes, an electronic ticker-feed, clusters of seating ranging from on-trend sofas to executive-meeting-style tables and chairs, a self-service bar and a bank of computer terminals. After the first thirty minutes, a number of members of the audience took up the general invitation to join the actors on the sofas, drinking at the bar, or posting comments on the onstage computer terminals, some of which were communicated via the ticker feed. Nine cameras filmed the action from different perspectives and were relayed live to various screens, which also cut to genuine or specially-recorded twenty-four hour news programmes. Surtitles were projected prominently above the stage, but also onto a selection of screens among the many intermedial projections, providing a creative illustration of interlinear translation.

While the proximity and prominence of the ITA surtitles reflect an emphasis on accessibility, their inclusion within the extensive production operation of audiovisual technology reveals the importance Van Hove places on intermedial techniques, the use of which he is prepared to defend: 'My theatre [practice] is sometimes criticised as no more than a massive presence of onstage technology. That's wrong! I only use it when it seems right, or at least 
justified ${ }^{8}$ (Maurin, 2014, p. 40). Van Hove rationalises the use of live-feed video as a key component in projecting empathy: 'For me, video is like a Greek mask: it enlarges things, it allows us to come nearer to the emotional dimension and to make it more visible, so that you can empathize more with that emotion' (Boenisch, 2014b, p. 58). Technology thus enhances connection with the human elements inherent in the production. This view extends to the dramaturgical team as a whole. Katalin Trencsényi provides a detailed account of Bart Van den Eynde's collaborative work as a dramaturg from the inception of the project to its staging, including his opinion that the production's subtitles use contemporary technology to involve the audience, which 'is not alien to Shakespeare's aims of addressing, involving and playfully teasing the audience and, instead of ignoring them, reflecting on what is happening in the theatre, constantly maintaining a live and active relationship with the spectators' (Trencsényi, 2015, p. 157). Here, technology is presented as a tool to recreate the timelessness of audience connection across temporal and spatial boundaries.

In London, however, there was an additional pressure on the surtitler: many members of the audience would be familiar with the original Shakespearean dialogue, and even more would expect certain set speeches and tags to be delivered verbatim. These were left essentially intact for the London production, the surtitles presenting a 'heightened English' and preserving, if at times updating, much of Shakespeare's imagery. These surtitles thus projected a somewhat different representation of the text that was actually spoken on stage. The Dutch language version reflected the set design: the actors used a modern, formal, public discourse of the kind heard in parliamentary debates. So the back-translated surtitles, while not exactly reverting to Shakespeare's original, neither exactly represent the full flavour of the Dutch dialogue.

\footnotetext{
${ }^{8}$ My translation.
} 
Furthermore, only Dutch-speaking spectators would have been able to recognise the distinction that Antony's voice was Dutch while the actor playing Cleopatra was Flemish.

David Willinger remarks on the significance of Van Hove's birth in Flanders for his relationship with the Dutch language, considering that 'the variants of speech sounds make a huge difference to the texture and emotional life of the theatre-going experience of [Van Hove's] Dutch-language productions' (Willinger, 2018, p. 116). Antony and Cleopatra were distinguished by their accents, a highlight of the differing backgrounds of Shakespeare's protagonists that had to be projected by alternate means to the non-Dutch-speaking audiences of touring productions. The surtitles reflected this by attributing more earthy language to Cleopatra. The Dutch word 'schurk', for example, was pronounced by Cleopatra for Shakespeare's 'villain', whereas the surtitles projected the word 'scum'. The intrusion of 'scum' was recounted by one of the reviewers, who considered that the Dutch translation and English surtitles, both composed by Tom Kleijn, 'produced clear and coherent surtitles, yet significantly diminished the beauty and precision of Shakespeare's language' (Scott, 2010, p. 354). It would appear, however, that Kleijn is acutely aware of the nuance required in this instance and very finely tuning his surtitles to reflect the performance.

The Dutch text must of necessity stand apart from the deeply-rooted cultural echoes that call to the English audience. What was portrayed, on stage and in the surtitles, was an interpretation of Shakespeare's text. This is no more a feature of translated theatre than of productions using the original text. Theatre is an interpretive and collaborative engagement between theatre practitioners and audience. Translation is one part of this engagement, and Van Hove's production of Roman Tragedies, by incorporating translated surtitles into the centre of the action, foregrounds the usually unseen translational processes, commenting on the role of 
Shakespearean drama in intercultural communications and the unidirectional nature of translation itself, moving away from the original but accumulating interpretive layers of additional culturality. The dramaturgical qualities of translation are symbolically represented in the surtitles.

The integration of surtitles within the intermedial approach of this production illustrates the operation of surtitles to convey deeper aspects of a production beyond interlingual codeswitching, not unlike the interlinear translation advocated by Benjamin. I argue that the inclusion of surtitles within technological production methodologies foregrounds the power of translation to communicate language and culture. Situating surtitles within the dramaturgical processes of the development and performance of production permits not only the text of the captions but also the 'virtual', between-the-lines, translation to be transmitted to the audience, supporting the production's comment on the original play. This human-nonhuman assemblage gives an example of how works of art generate active environments. Parikka defines posthuman ecologies as 'multiple layers of time, dynamics and duration that extend much further than the anthropocentric bias would allow' (2019, p. 57). Intermedial theatre practices invite theatre practitioners and audiences to engage with contemporary and classical narratives, synchronised within a single text, mediated through translation and performance.

In Roman Tragedies, for example, Van Hove's stated aim to focus on the public persona of Shakespeare's characters is further developed by the use of intermedial techniques. 'Political power is represented through a disclosure of stagecraft in which theatrical and mediatized effects like makeup, recording technology, and cinematography are shown to produce public figures' (Corbett and Zaiontz, 2011, p. 118). Surtitles and captions are written into the production to support this intermedial stagecraft. According to Laurens De Vos, 'Set in what could have been a 
newsroom, Roman Tragedies was an explicit comment on one of the most popular television programmes of the decade, Big Brother, [...] there was no escape from the all-seeing eye of the cameras' (De Vos, 2018, p. 69). As Braidotti and Hlavajova point out, post-industrial technology plays 'a crucial role in defining the posthuman moment by stressing the primacy of digital mediation and electronic circuits in our self-definitions and interaction' (2018, p. 2). The dramaturgy of surtitles as part of the proliferation of screens and text serves to underline the blurring between public and private persona that Van Hove projected with the intense use of video media onstage. The encounters within the production - between classical history and contemporary design, between theatre practitioners and audience, between spoken Dutch and English text - are reinforced and reframed by the intermingling of technology with human performance and emotion.

\section{Conclusion}

It is W. B. Worthen's hope that 'the friction between texts and enactment in contemporary performance might help us to find the pulse of Shakespearean performativity' (2001, p. 137). In this article, I have investigated the embodiment of that friction in the form of surtitles, interrogating the role of translation in conveying the force of Shakespeare's text to modern audiences. 'In the theatre', claims Worthen, 'if we want to speak with the dead, we can only do so through the recalcitrant behaviour of the living' (2001, p. 137). Examining the positioning and textual choices in the surtitles of Roman Tragedies demonstrates the extent to which translational resistance, or recalcitrance, contributes to the conveyance of synchronic and diachronic meaning. Innovative use of and engagement with digital media enhances this interpretive communication. But are the innovative surtitles I have described merely a result of technological advances and the increasing internationalisation of productions developed for touring? As Estella Oncins 
points out, 'rapid technological developments have opened up new surtitling possibilities' (2015, p. 43). I argue that, whether intentional or incidental, captioning technology, in the process of improving accessibility to theatrical translation, has brought surtitling into the realm of dramaturgy and performance and created an environment for human-posthuman assemblage.

Patrice Pavis notes that surtitles 'can be integrated into the productions visuals like calligraphy', adding 'another level of perception' (2013, p. 138), although he sees them as a reintroduction of text into performance. In my view, the use of surtitles to convey translation allows an original text to project more than just a shift in language. For the productions of which Roman Tragedies is an example, translation is not only textually visible, it is also playful. New technology permits intermediality, including surtitles, to support the iconicity or iconoclasm of a production, reaching beyond textual aspects. As Michael Billington writes in his essay 'Shakespeare in Europe', 'something strange happens when you lose the English language and context: you release the play's metaphorical power' (1993, p. 357). The surtitles point to that release and rediscovery or reinvestigation of a play's core content. The incorporation of surtitles into the heart of the production rather than banishing them to the wings brings us back to Benjamin's interlinear translation, where surtitles become an independent stage dialogue emerging from the production to contribute to the overarching meta-language of theatre and the humanity of performance.

\section{References}

Alexander, C. (2010). Complicite - The Elephant Vanishes (2003/4) - 'The Elephant and Keeper Have Vanished Completely...They Will Never Be Coming Back'. In J. Harvie \& A. Lavender (Eds.), Making Contemporary Theatre: International Rehearsal Processes (pp. 59-80). Manchester: Manchester University Press.

Balme, C. (2008). Surrogate Stages: Theatre, Performance and the Challenge of New Media. Performance Research, 13(2), pp. 80-91. doi:10.1080/13528160802639342

Benjamin, W. (1968). The Task of the Translator. Delos (1), pp. 76-96. 
Billington, M. (1993). One Night Stands: A Critic's View of British Theatre from 1971 to 1991 London: Nick Hern Books.

Boenisch, P. (2014a). Acts of Spectating: Dramaturgy of the Audience's Experience in Contemporary Theatre. In K. Trencsényi \& B. Cochrane (Eds.), New Dramaturgy: International Perspectives on Theory and Practice (pp. 225-241). London: Bloomsbury.

Boenisch, P. (2014b). Creating X-Rays of the Text to Dissect the Present: Ivo van Hove of Toneelgroep Amsterdam in Conversation with Peter M. Boenisch. In M. Laera (Ed.), Theatre and Adaptation: Return, Rewrite, Repeat (pp. 49-61). London: Bloomsbury.

Braidotti, R., \& Hlavajova, M. (2018). Introduction. In R. Braidotti \& M. Hlavajova (Eds.), Posthuman Glossary (pp. 1-14). London: Bloomsbury Academic.

British Theatre Conference. (2015). British Theatre Repertoire 2013: Report by the British Theatre Consortium, UK Theatre, and the Society of London Theatre. http://britishtheatreconference.co.uk/wp-content/uploads/2015/05/British-TheatreRepertoire-2013.pdf

Brodie, G. (2018). Indirect Translation on the London Stage: Terminology and (In)visibility. Translation Studies, 11(3), pp. 333-348.

Burton, J. (2009). The Joy of Opera: The Art and Craft of Opera Subtitling and Surtitling. In I. Kemble (Ed.), The Changing Face of Translation: Proceedings of the Eighth Annual Portsmouth Translation Conference Held on 8 November 2008 (pp. 28-34). Portsmouth: University of Portsmouth.

Carlson, M. (2006). Speaking in Tongues: Language at Play in the Theatre Ann Arbor: University of Michigan Press.

Corbett, N., \& Zaiontz, K. (2011). The Politics of Distraction: Spectatorial Freedom and (dis)Enfranchisement in Toneelgroep's Roman Tragedies. Canadian Theatre Review, 147 (1), pp. 117-120.

Cremo, P. (2014, 23 May 2014). [Met Titles Request].

De Vos, L. (2018). Staging Shakespeare at Toneelgroep Amsterdam: Political Murders and Backgroom Politics. In S. Bennett \& S. Massai (Eds.), Ivo van Hove: From Shakespeare to David Bowie (pp. 68-71). London: Methuen Drama.

Desblache, L. (2012). Hybridity, Monstrosity and the Posthuman in Philosophy and Literature Today. Comparative Critical Studies, 9(3), pp. 245-255. doi:10.3366/ccs.2012.0061

Desblache, L. (2013). Tales of the Unexpected: Opera as a New Art of Glocalization. In H. J. Minors (Ed.), Music, Text and Translation (pp. 22-38). London: Bloomsbury.

Díaz-Cintas, J., \& Anderman, G. (2009). Introduction. In J. Díaz-Cintas \& G. Anderman (Eds.), Audiovisual Translation: Language Transfer on Screen (pp. 1-17). London: Palgrave Macmillan.

Eckersall, P., Grehan, H., \& Scheer, E. (2015). New Media Dramaturgy. In M. Romanska (Ed.), The Routledge Companion to Dramaturgy (pp. 375-380). Abingdon: Routledge.

Griesel, Y. (2009). Surtitling: Surtitles an Other Hybrid on a Hybrid Stage. Trans(13), pp. 119127.

Hillman, R. (2011). Spoken Word to Written Text: Subtitling. In K. Malmkjaer \& K. Windle (Eds.), The Oxford Handbook of Translation Studies (pp. 379-393). Oxford: Oxford University Press.

Karamitroglou, F. (2000). Towards a Methodology for the Investigation of Norms in Audiovisual Translation: The Choice Between Subtitling and Revoicing in Greece Amsterdam: Rodopi. 
Kruger, J.-L. (2008). Subtitler Training as Part of a General Training Programme in the Language Profession. In J. Díaz-Cintas (Ed.), The Didactics of Audiovisual Translation (pp. 71-87). Amsterdam: John Benjamins.

Ladouceur, L. (2013). Exploring a Bilingual Aesthetics through Translation in Performance. In S. Bigliazzi, P. Kofler \& P. Ambrosi (Eds.), Theatre Translation in Performance (pp. 111-129). New York: Routledge.

Lehmann, H.-T. (2016). Tragedy and Dramatic Theatre (E. Butler, Trans.) Abingdon: Routledge.

Lim, A. E. H. (2020). Multilingual Dramaturgy and Staging Relevant Translations in Singapore. In Y. Meerzon \& K. Pewny (Eds.), Dramaturgy of Migration: Staging Multilingual Encounters in Contemporary Theatre (pp. 88-99). Abingdon: Routledge.

Männaste, M. (2019, 22 October 2019). [Surtitles and the Sophokles App].

Maurin, F. (2014). Ivo van Hove: Introduction et Entretiens Arles: Actes Sud.

McAuley, G. (1999). Space in Performance: Making Meaning in the Theatre Ann Arbor: University of Michigan Press.

McCullagh, S. (2019). Heterogeneous Collectivity and the Capacity to Act: Conceptualising Nonhumans in Political Space. In R. Braidotti \& S. Bignall (Eds.), Posthuman Ecologies: Complexity and Process after Deleuze (pp. 141-158). New York: Rowman and Littlefield.

Menke, U. (2015, 8 June 2015). [Surtitling].

Nestruck, J. K. (2010, 17 May 2010). Roman Tragedies: It's Quite the Caesar Sandwich. Globe and Mail. Retrieved from https://www.theglobeandmail.com/arts/theatre-andperformance/roman-tragedies-its-quite-the-caesar-sandwich/article4320579/

Oncins, E. (2015). The Tyranny of the Tool: Surtitling Live Performances. Perspectives: Studies in Translation Theory and Practice, 23(1), pp. 42-61.

operatraveller.com. (2017). Guide to Theatres and Titling Systems. Retrieved Date 21 October 2019 from https://operatraveller.com/2017/01/08/guide-to-theatres-and-titling-systems/.

Parikka, J. (2019). Cartographies of Environmental Arts. In R. Braidotti \& S. Bignall (Eds.),

Posthuman Ecologies: Complexity and Process after Deleuze (pp. 41-60). New York: Rowman and Littlefield.

Pavis, P. (2013). Contemporary Mise en Scène: Staging Theatre Today Abingdon: Routledge.

Pérez González, L. (2020). Audiovisual Translation. In M. Baker \& G. Saldanha (Eds.), Routledge Encyclopedia of Translation Studies (Third ed., pp. 30-34). Abingdon: Routledge.

Perrier, J.-F. (2009). The World of Politics: Ivo van Hove in Conversation Roman Tragedies. London: Barbican Centre.

Postlewait, T. (2010). Mise-en-Scène In D. Kennedy (Ed.), The Oxford Companion to Theatre and Performance (pp. 396). Oxford: Oxford University Press.

Rancière, J. (2008). The Emancipated Spectator (G. Elliott, Trans.) London: Verso.

Read, A. (2010). Romeo Castellucci: The Director on This Earth. In M. M. Delgado \& D. Rebellato (Eds.), Contemporary European Theatre Directors (pp. 249-262). Abingdon: Routledge.

Remael, A. (2010). Audiovisual Translation. In Y. G. L. v. Doorslaer (Ed.), Handbook of Translation Studies (Vol. 1, pp. 12-17). Amsterdam: John Benjamins.

Rowe, K. (2010). From the Editor: Gentle Numbers. Shakespeare Quarterly, 61(3), pp. iii-viii. 
Royal Opera House Covent Garden Foundation. (2019). Access. Retrieved Date 21 October 2019 from https://www.roh.org.uk/visit/access.

Scott, S. K. (2010). Roman Tragedies, Coriolanus, Julius Caesar, Antony and Cleopatra (review). Shakespeare Bulletin, 28(3), pp. 347-356.

Secar, A. (2018). Surtitling and Captioning for Theatre and Opera. In L. Pérez-González (Ed.), The Routledge Handbook of Audiovisual Translation (pp. 130-144). Abingdon: Routledge.

Todoruţ, I. (2015). Dramaturgies for the Digital Age. In M. Romanska (Ed.), The Routledge Companion to Dramaturgy (pp. 495-499). Abingdon: Routledge.

Toneelgroep Amsterdam. (2017). Surtitled in Amsterdam. Retrieved Date 29 May 2018 from https://tga.nl/en/about-ta/surtitled-in-amsterdam.

Trencsényi, K. (2015). Dramaturgy in the Making: A User's Guide for Theatre Practitioners London: Bloomsbury Methuen Drama.

Vanemuine Theatre. (2018). Wiener Blut (Viini Veri). Retrieved Date Accessed, 2019 from https://www.vanemuine.ee/repertuaar/wiener-blut-viini-veri/?lang=en.

Venuti, L. (2008). The Translator's Invisibility (Second ed.) Abingdon: Routledge.

Versényi, A. (2010). Dramaturgy/Dramaturg. In D. Kennedy (Ed.), The Oxford Companion to Theatre and Performance (pp. 176). Oxford: Oxford University Press.

Willinger, D. (2018). Van Hove, Virtuoso. In D. Willinger (Ed.), Ivo van Hove Onstage (pp. 1235). Abingdon: Routledge.

Worthen, W. B. (2001). Shakespearean Performativity. In M. Bristow, K. McLuskie \& C. Holmes (Eds.), Shakespeare and Modern Theatre: The Performance of Modernity (pp. 117-141). London: Routledge. 